\title{
Mpororoite and anthoinite from the Kara mine, Tasmania
}

\author{
Satoshi Matsubara, Akira Kato \\ Department of Geology, National Science Museum, 3-23-1 Hyakunin-cho, Shinjuku, Tokyo 160, Japan \\ AND \\ Kozo Nagashima \\ Department of Chemistry, The University of Tsukuba, Sakura-mura, Ibaraki 305, Japan
}

\begin{abstract}
The first occurrence of mpororoite and anthoinite outside the African Continent has been found in an altered skarn from the Kara mine, Tasmania, forming a white powdery mixture of the two minerals pseudomorphing scheelite. The wet chemical analysis of the mixture shows $\mathrm{WO}_{3}, \mathrm{Al}_{2} \mathrm{O}_{3}$, and $\mathrm{H}_{2} \mathrm{O}$ to be the essential constituents, proving the non-essential nature of $\mathrm{Fe}_{2} \mathrm{O}_{3}$ in mpororoite; the original mpororoite contained high $\mathrm{Fe}_{2} \mathrm{O}_{3}$ substituting for $\mathrm{Al}_{2} \mathrm{O}_{3}$. The thermal treatment of the mixture at $100^{\circ} \mathrm{C}$ for 6 hours in air brings about the conversion of mpororoite into anthoinite, which re-hydrates into mpororoite, although the associated anthoinite does not. The source of $\mathrm{Al}$ is ascribed to the decomposition of aluminian andradite in the skarn.
\end{abstract}

IN 1980 the first author visited the Kara mine, Tasmania, as a member of Geological Survey Team of the National Science Museum, Japan, and collected some specimens of altered skarn from the trench and open pit of the ore deposit. The X-ray powder and chemical studies demonstrated the presence of mpororoite and anthoinite, forming a powdery mixture occasionally pseudomorphing scheelite which is the principal ore mineral of the deposit.

The present paper is the first report of their co-existence and occurrence in a contact metasomatic deposit. The chemical analysis of the mixture yields a formula $\mathrm{WAlO}_{3}(\mathrm{OH})_{3} \cdot n \mathrm{H}_{2} \mathrm{O}$ with only a small amount of substitution of $\mathrm{Fe}_{2} \mathrm{O}_{3}$ for $\mathrm{Al}_{2} \mathrm{O}_{3}$, proving the non-essential nature of $\mathrm{Fe}_{2} \mathrm{O}_{3}$ in mpororoite from the original locality. The thermal treatment of the mixture shows $\mathrm{H}_{2} \mathrm{O}$ in mpororoite to be zeolitic; that is, artificially dehydrated mpororoite re-hydrates on treatment with $\mathrm{H}_{2} \mathrm{O}$ under room temperature conditions.

Occurrence and description of the studied materials. The ore deposit of the Kara mine is located about $40 \mathrm{~km} \mathrm{SSW}$ of Burnie, Northwestern Tasmania,
Australia. It is developed in contact metamorphosed late Ordovician or early Devonian sedimentary rocks belonging to Junee Group, intruded by a biotite granite of early Devonian to late Carboniferous age (Williams and Turner, 1973). The ore deposit is worked for tungsten and the principal and unique ore mineral is scheelite, which is dominantly formed in hedenbergite-actinolitemagnetite skarn forming a thin roof-pendant on the granite (Wolff, 1978).

The studied materials were from the wall of the old trench and the uppermost part of the open pit. In the former, the skarn minerals are completely altered to yellowish-green earthy montmorillonite, in which white to grey-white aggregates of powdery mpororoite and anthoinite, reaching a few centimetres across, are found (fig. 1). In the exposure the powder is mobilized downward along the fractures and exposure surface. No discrimination of the two was possible without X-ray powder diffraction work. A very small amount of scheelite is left unaltered as minute grains in the powdery aggregates. In the open pit materials the mixture of mpororoite and anthoinite contains varying amounts of scheelite and is found in a magnetiterich skarn in which the constituent silicates are completely altered into light-brown earthy halloysite (fig. 2). In both places much unaltered scheelite is found in a magnetite skarn or in a garnet skarn closely associated with the magnetite skarn.

A comparison of the altered and unaltered skarn shows that the original skarn was rich in an aluminian andradite, comprising about 20 mole \% of the grossular molecule, and the alteration could be the source of Al now contained in mpororoite and anthoinite. The alteration is a kind of decomposition accompanied by removal of Al. All the aggregates examined consisted of mpororoite 

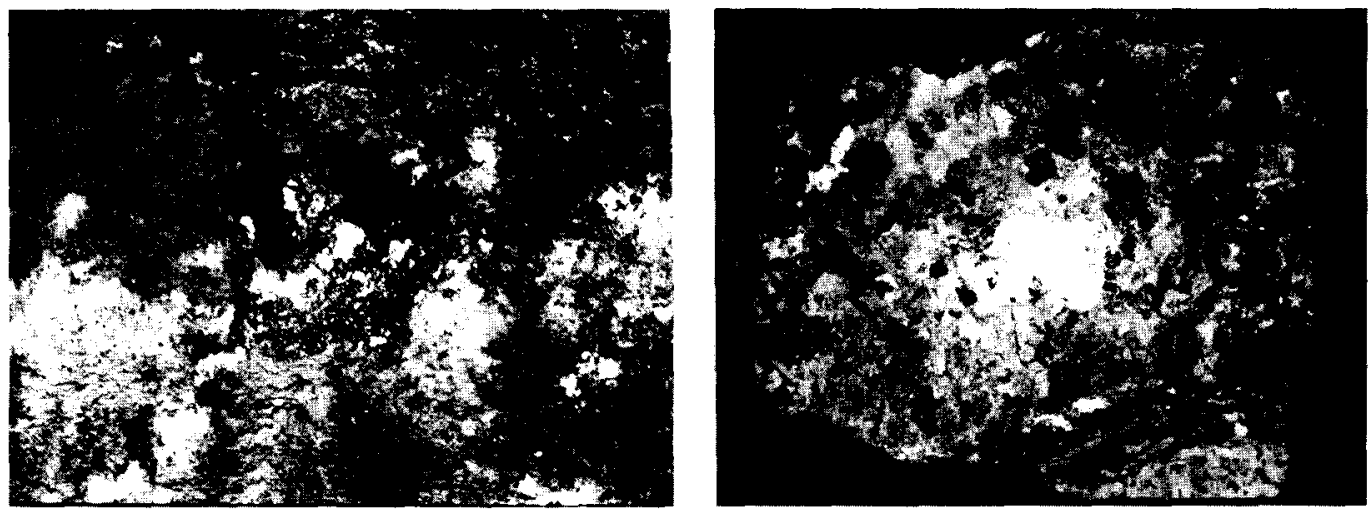

FIGs. 1 and 2. FIG. 1 (left). The mode of occurrence of the mixture of mpororoite and anthoinite (white) in altered skarn at the trench No. 1. Field view, approx. $50 \times 35 \mathrm{~cm}$. Fig. 2 (right). The mixture of mpororoite and anthoinite pseudomorphing scheelite (white in centre) in altered skarn. The specimen, approx. $10 \times 7 \mathrm{~cm}$.

and anthoinite, although the quantitative ratio changed from unity to anthoinite-rich, reaching an approximate ratio of $1: 3$, based on a direct comparison of the relative intensity of the strongest $\mathrm{X}$-ray powder diffraction peaks. The present find is the first example of the co-existence of the two hydrous tungstates of aluminium and of their occurrence in a contact metasomatic scheelite deposit. Also, this is the first occurrence of these minerals outside the African Continent.

$X$-ray powder diffraction study. The separation of two minerals was impossible owing to their extremely fine grain size. Therefore, the $\mathrm{X}$-ray powder study was made on the mixed specimens collected from the trench and open pit, and the pattern of the former (from trench No. 1, NSM FM-7799) is presented in Table I, together with those of mpororoite (von Knorring et al, 1972) and anthoinite (Sahama et al., 1970). No meaningful derivation of unit cell parameters was possible due to some overlapping diffraction peaks. The tabulated pattern is for the best crystallized material with a high ratio of mpororoite to anthoinite.

Although the proposed formulae of mpororoite and anthoinite are $(\mathrm{W}, \mathrm{Al})(\mathrm{O}, \mathrm{OH})_{3} \cdot \mathrm{H}_{2} \mathrm{O}$ and $(\mathrm{W}, \mathrm{Al})(\mathrm{O}, \mathrm{OH})_{3}$ respectively, the present analysis indicates the ratio $\mathrm{W} / \mathrm{Al}$ or $\mathrm{W} /(\mathrm{Al}+\mathrm{Fe})$ to be unity, corroborating the suggestion of Sahama (1981). That is, their ideal formulae, should be $\mathrm{WAlO}_{3}$ $(\mathrm{OH})_{3} \cdot 2 \mathrm{H}_{2} \mathrm{O}$ and $\mathrm{WAlO}_{3}(\mathrm{OH})_{3}$, respectively, and their unit cells must be at least doubled to meet their unit cell contents.

The X-ray powder diffraction patterns of the inner and outer parts of aggregates from the open pit indicate that they consist mainly of anthoinite with small amounts of scheelite and mpororoite, and also the amount and crystallinity of mpororoite increase outwards, whereas the amount of scheelite decreases. From this evidence scheelite is considered to have been altered firstly into anthoinite and subsequently into mpororoite.

The X-ray powder diffraction studies were also made on the dehydrated and re-hydrated materials. The former includes two samples prepared by heating the mixture at $100^{\circ} \mathrm{C}$ for 2 and 6 hours. As

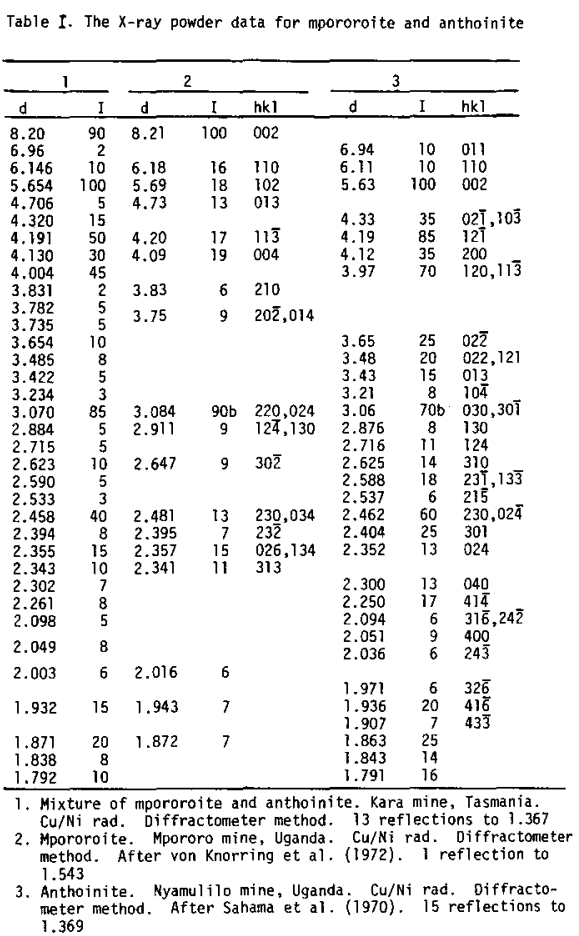




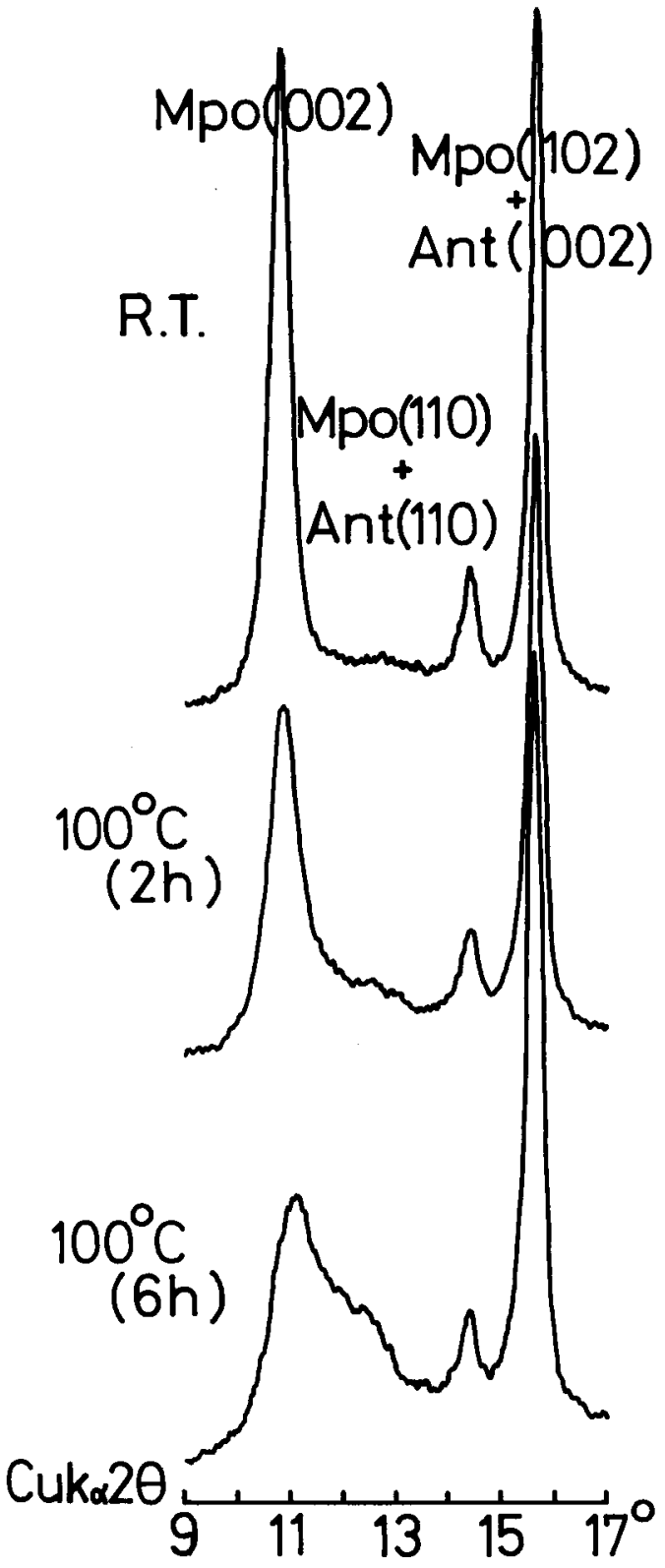

Fig. 3. Thermal change of $\mathrm{X}$-ray diffraction diagrams for the mixture of mpororoite (Mpo) and anthoinite (Ant).

demonstrated in fig. 3, the diffraction lines of mpororoite decrease in sharpness and intensity and shift toward the higher angle side, and those of anthoinite increase in relative intensity. When the heated material is soaked in $\mathrm{H}_{2} \mathrm{O}$ under room temperature conditions, the intensity of diffraction peaks of mpororoite tends to increase once again.
The size difference between their respective unit cells is principally seen in spacings with the contribution responsible for $c^{*}$, suggesting the presence of a layer structure perpendicular to $c^{*}$. This structure would allow the siting of interlayer water with a zeolitic nature in mpororoite, which may be responsible for the stronger $(00 l)$ diffractions.

\section{Chemical composition}

The chemical analysis of the X-rayed material is given in Table II, where those of mpororoite from

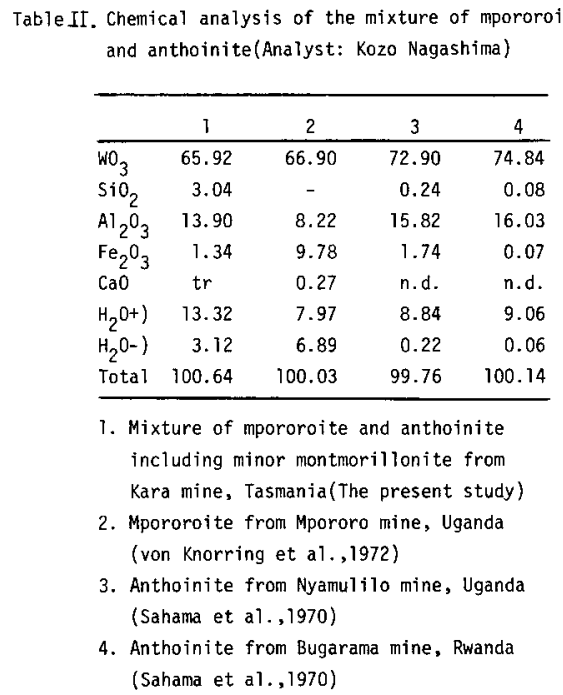

the Mpororo mine (von Knorring et al., 1972) and of anthoinite from the Nyamulili mine, Uganda, and of Bugawara mine, Rwanda (Sahama et al., 1970), are also given. In addition to the major elements, $\mathrm{Mo}, \mathrm{Ca}$, and $\mathrm{Mg}$ are found as minor constituents. Also, the present material contains a small amount of $\mathrm{SiO}_{2}$, which can be ascribed to admixed montmorillonite. The empirical formula derived from the analysis is: $\left(\mathrm{W}_{0.52} \mathrm{Al}_{0.46} \mathrm{Fe}_{0.02}^{3+}\right)_{\Sigma 1.00}$ $\left(\mathrm{O}_{1.56}(\mathrm{OH})_{1.44}\right)_{\Sigma 3.00} \cdot 0.59 \mathrm{H}_{2} \mathrm{O}$ on the basis of $\mathrm{W}+\mathrm{Al}+\mathrm{Fe}^{3+}=1$ after the deduction of $\mathrm{SiO}_{2}$ etc., as an iron-bearing montmorillonite with the estimated composition $\mathrm{SiO}_{2} \cdot 0.21 \mathrm{Al}_{2} \mathrm{O}_{3} \cdot 0.06 \mathrm{Fe}_{2} \mathrm{O}_{3}$. $0.45 \mathrm{H}_{2} \mathrm{O}$. This corresponds to an intermediate composition between mpororoite and anthoinite with an approximate mole ratio $6: 4$.

The formation of mpororoite and anthoinite needs a supply of $\mathrm{H}_{2} \mathrm{O}$ and $\mathrm{Al}_{2} \mathrm{O}_{3}$ and the leaching of a large quantity of calcium from scheelite and iron plus calcium from garnet. Such conditions are thought to have only rarely been attained, and 
the occurrence of mpororoite and anthoinite is uncommon, despite the existence of numerous skarn-type scheelite deposits in the world.

Acknowledgements. The authors are greatly indebted to McIntyre Mines (Australia) Pty. Ltd. and Tasmania Department of Mines for permitting collection of specimens and field observation.

\section{REFERENCES}

Sahama, Th. G. (1981) Mineral. Record, 12, 81-7.
_- von Knorring, O., and Lehtinen, M. (1970) Bull. Geol. Soc. Finland, 42, 95-9.

von Knorring, O., Sahama, Th. G., and Lehtinen, M. (1972) Ibid. 44, 107-10.

Williams, E., and Turner, N. J. (1973) Geological Atlas (1:250,000 Series), Burnie. Tasmania, Department of Mines.

Wolff, G. C. (1978) Geology and Mineralization of N. W. Tasmania, 37-8. Geol. Soc. Australia Inc. Tasmania Division.

[Manuscript received 26 October 1983] 